\title{
Blessing the rains down in Africa: spatiotemporal behaviour of the crested porcupine Hystrix cristata (Mammalia: Rodentia) in the rainy and dry seasons, in the African savannah
}

\author{
Andrea Viviano ${ }^{1}$, Giovanni Amori ${ }^{2}$, Luca Luiselli ${ }^{3}$, Horst Oebel ${ }^{4}$, Farid Bahleman ${ }^{4}$ and \\ Emiliano Mori ${ }^{5^{*}}$
}

${ }^{1}$ Dipartimento di Scienze Agrarie, Alimentari e Agro-ambientali, Produzioni Agroalimentari e Gestione degli Agroecosistemi, Università degli Studi di Pisa, Italy; ${ }^{2}$ Consiglio Nazionale delle Ricerche, Istituto di Ricerca sugli Ecosistemi Terrestri, Rome, Italy; ${ }^{3}$ Institute for Development, Ecology, Conservation and Cooperation, Rome, Italy; Department of Applied and Environmental Biology, Rivers State University of Science and Technology, Port Harcourt, Nigeria; ${ }^{4}$ Program Transboundary Biosphere Reserve WAP Region, Deutsche Gesellschaft für Internationale Zusammenarbeit, Cotonou, Benin; ${ }^{5}$ Consiglio Nazionale delle Ricerche, Istituto di Ricerca sugli Ecosistemi Terrestri, Sesto Fiorentino, Italy

Received for publication: 29 November 2020; Revision received: 18 December 2020; Accepted for publication: 23 December 2020.

\begin{abstract}
The assessment of habitat selection and temporal patterns of activity rhythms is paramount for wildlife conservation. Studies on behavioural ecology of wild mammals are particularly challenging in tropical areas, mostly when involving rare or elusive species. Despite being a common species in Italy, the crested porcupine Hystrix cristata is threatened of extinction throughout most of its sub-Saharan range. All available information on the ecology of this species has been collected in Italy, whereas no data is present in the scientific literature on spatiotemporal behaviour of this large rodent in Africa. In this work, we attempted to determine habitat selection and temporal patterns of activity rhythms of the crested porcupine in northern Benin and neighbouring countries, through intensive camera-trapping. We collected a total of 146 records of crested porcupine, 91 in the dry season (October-March) and 55 in the rainy season (April-September). Porcupines used most habitats in proportion to their local availability, while selecting rock outcrop formations (possibly used as shelter sites) and avoiding open areas, wetlands and gallery forests. A mostly nocturnal behaviour was confirmed throughout the year, with some diurnal activity at the start and at the end of the rainy season. The importance of rains in determining birth peak has been also showed, with juvenile individuals always observed at the start and at the end of the rainy season. Full moon always inhibited activity of this large rodent, most likely evolved as an antipredatory behaviour to limit encounters with potential predators (common leopard Panthera pardus, spotted hyaena Crocuta crocuta and honey badger Mellivora capensis) and humans. Poaching pressure towards porcupines in West Africa is strong. Porcupines are killed for the traditional medicine, for their meat and because they are widely considered as a crop pest. This assessment should therefore be used as a basic tool to design conservation plans to preserve this rodent species in its native range.
\end{abstract}

\footnotetext{
*Corresponding author. E-mail: emiliano.mori@cnr.it

${ }^{\circ}$ Copyright: the Author(s), 2020 | Licensee PAGEPress, Italy
} 
Key words: Activity patterns; habitat selection; moonlight avoidance; native range; wildlife camera-trapping.

\section{Introduction}

The assessment of the spatiotemporal behaviour of wildlife species is important for conservation and management programs, particularly to preserve rare and elusive species, and to manage pest or invasive species (Di Bitetti et al. 2006; Valeix et al. 2009; Caravaggi et al. 2017; Karanth et al. 2017; Ossi et al. 2020). Wild mammals may show different patterns of habitat use, diet and temporal activity rhythms in the different areas of their range and at different population densities (Bridges and Noss 2011; Soe et al. 2017; Bonnot et al. 2019; Hinckley et al. 2020). This is particularly evident for species showing wide native distribution ranges (e.g., Gehring et al. 2003; Díaz-Ruiz et al. 2016; Karanth et al. 2017), and for those introduced in new environments (Cox 2004; Drygala et al. 2008; Blight et al. 2017; Luna et al. 2017). The estimation of habitat use/selection and patterns of activity rhythms may be challenging, particularly for those species inhabiting jungles, thick scrublands, high mountains or other geographical areas which are hard to be investigated (De Luca and Rovero 2006; Bowkett et al. 2008; Botts et al. 2020; Lovari et al. 2020; Ossi et al. 2020). In these contexts, camera-traps have provided important ecological information on the behaviour of a high number of species (Tobler et al. 2008; Rovero et al. 2008, 2010; Hamel et al. 2013; Caravaggi et al. 2017), when a remarkable number of records is collected (i.e., at least 30 per species: Lashley et al. 2018).

The crested porcupine Hystrix cristata Linnaeus, 1758 is a large rodent, and its body mass may reach up to $15-17 \mathrm{~kg}$ (Mori and Lovari 2014). The distribution of this species is scattered and encompasses the whole North Africa, from Morocco to Lybia and a savannah belt south to the Sahara Desert ranging from Senegal to Ethiopia and Tanzania (Amori and De Smet 2016; Mori et al. 2019). A population of this species also occurs in Italy, as a result of an ancient introduction (Trucchi et al. 2016; Mori et al. 2018, 2019). Similarly, few individuals of this species are also present in the Sinai Peninsula, Egypt (Trucchi et al. 2016). In central and southern Tanzania, the range of $H$. cristata partly overlaps with that of the closely related $H$. africaeaustralis Peters, 1852 (Trucchi and Sbordoni 2009). The ecology of this species, i.e., orientation (Massolo et al. 2009), use of den setts (Pigozzi 1986; Monetti et al. 2005), habitat use/selection (Pigozzi and Patterson 1991; Mori et al. 2014a; Mori 2017), patterns of activity rhythms (Mori et al. 2014c; Lovari et al. 2017), diet (Bruno and Riccardi 1995), reproductive behaviour (Mori et al. 2016) and interspecific interactions (Mori et al. 2014b; Lazzeri et al. 2020) have been studied mostly in the introduced range, i.e., in Italy. Ecology and behavioural biology of the crested porcupine in its native range are mostly unknown, a part from a study on its diet in Tunisia (Ettiss et al. 2020), which reported that this rodent is mostly a consumer of grasses and cultivated species. Mouzoun et al. (2018a) attempted to assess habitat selection by the crested porcupine in Western Africa by collecting signs of presence and occasional observations. This method may provide several misinterpretations, as signs of presence (i.e., quills, excrements, footprints) may not be equally detectable in all habitat types (e.g., Romani et al. 2018). In Western Africa (e.g., Ghana, Benin, Niger and Burkina Faso), the crested porcupine is threatened with extinction, with apparently declining populations because of habitat loss, poaching, bushmeat overexploitation (Mouzoun et al. 2018b), traditional medicine and mystic practices (Ouoba et al. 2020). This highlights the need to assess its spatial and temporal behaviour in these areas, so to trigger reliable conservation actions for its preser- 
vation (Amori and De Smet 2016). In recent times, camera-trapping has been shown to be effective in assessing spatiotemporal behaviour of crested porcupines, even in areas hard to be directly investigated and even when the porcupine is not the target species of the camera-trap survey (e.g., Fattorini and Pokheral 2012; Mazzamuto et al. 2019). A citizen science project on the iNaturalist platform including data collected through camera-trapping since 2011 has allowed researchers to access to biodiversity data on protected areas of Western Africa (Schmidt et al. 2016). Aims of this work were to describe habitat use and patterns of activity rhythms of the threatened crested porcupine in western Africa. We predicted that $(i)$ the crested porcupine will show a generalist behaviour in terms of habitat selection (Santini 1980; Pigozzi and Patterson 1990), (ii) with mostly nocturnal habits throughout the year. We also expected that (iii) crested porcupines would exhibit moonlight avoidance (Mori et al. 2014c) to limit potential encounters with its main predators, i.e. the common leopard Panthera pardus (Linnaeus, 1758), the spotted hyaena Crocuta crocuta Erxleben, 1777 and the honey badger Mellivora capensis (Schreber, 1776).

\section{Materials and methods}

\section{Study area}

Our study was conducted in an area of about 850,000 ha, encompassing northern Benin, southwestern Niger and eastern Burkina Faso, including transboundary reserves between these countries. The study area was covered with shrub savannah (33\%), arboreal savannah $(30 \%)$, gallery forests $(20 \%)$, rock outcrop formations $(11 \%)$, wetlands $(5 \%)$ and fallows $(1 \%$ : Mouzoun et al. 2018a). The study area has a typical tropical climate, with rainy season concentrated between April and September, but with rainfall peaks in August and September.

Monitoring of wildlife through camera-trapping has increased in the W-Arly-Pendjari (herafter, WAP) complex in the last 10 years, particularly in the Pendjari National Park, before being extended to other Protected Areas of WAP (Arly, West Niger, Burkina-Faso and Benin).

\section{Sampling design}

Data collection was conducted between January 2011 and April 2020. Camera -traps (Maginon, Victure, Tec.Bean, SpyPoint ${ }^{\mathrm{TM}}$ Force-10, Browning Strike Force HD Pro, PenCam Camera-Traps, $\mathrm{N}=175$ ) were placed at 175 stations, i.e., fixed georeferenced locations (i.e., to shrubs, sand pits or rocks) where each camera-trap was tied with ropes and chains, at a height of $\sim 40-50 \mathrm{~cm}$ from the ground, in all habitat types (Monterroso et al. 2014). Stations were separated one-another by at least $10 \mathrm{~km}$, to limit pseudoreplication bias (O'Connell et al. 2011). We built up a regular grid ( side $=10 \mathrm{~km}$ ) through QGIS (QGIS Development Team 2019). Cameras were placed in the center of each randomly selected $100 \mathrm{~km}^{2}$ cell, or in its immediate surroundings ( $\max$. distance from cell center $=2 \mathrm{~km}$ ), opportunistically on wildlife trails or at water points to maximise camera-trapping success. We removed the grass in front of the cameras to prevent vegetation from triggering the cameras which were configured to work continuously ( $24 \mathrm{~h}$ a day), to take 1 picture/animal passage. Camera-traps were checked once every 2 weeks to download data and replace dead batteries.

\section{Habitat selection}

Habitat types were assessed by camera-trap shots and confirmed through satellite photos on Google Earth. We calculated the Ivlev's electivity index (Ivlev 1961) to assess the habitats selection of crested porcupine, through the statistical software R 3.1.1, package gplots 
(Warnes et al. 2014). This index compares the availability of each habitat type with its use by the species according to the formula $E=\left(U_{i}-A_{i}\right) /\left(U_{i}+A_{i}\right)$, where $U_{i}$ is the proportion of use of habitat " $i$ " and $A_{i}$ is its local availability. The values of this index ranged from -1 to +1 , with values between -1 and 0 indicating avoidance, and values from 0 to +1 indicating preference for a habitat type. A true selection or avoidance can be declared only at values $>0.3$ or $<-0.3$, respectively (Lazzaro 1987; Laurenzi et al. 2016).

\section{Patterns of activity rhythms}

Our dataset was divided into two periods (dry season: October-March; rainy season: April-September: Dossou-Yovo et al. 2016), to conduct analyses on both total-year and seasonal scales. The "activity" was defined as the cumulate period spent by porcupines outside dens (Lashley et al. 2018). Photographs of porcupines were downloaded from iNaturalist; date and the solar hour of capture directly shown on each capture were then reported on a dataset. We identified juvenile (including cubs) and adult individuals according to body size, i.e. with juveniles being about $25-30 \%$ smaller than adults (e.g., Mori et al. 2016). Records occurring at the same site within less than 30 min were removed from the dataset to limit pseudoreplication (Meredith and Ridout 2014). Seasonal patterns of activity rhythms of the crested porcupine and their 95\% confidence intervals (hereafter, CIs) were computed through the R 3.6.1 package "overlap" (Meredith and Ridout 2014). We estimated the coefficient of overlapping $(\Delta)$ between temporal activity patterns of the crested porcupine in the dry and rainy seasons. The coefficient of overlapping ranges between 0 (no overlap) and 1 (total overlap: Meredith and Ridout 2014). We calculated the $\Delta_{4}$ estimator and its 95\% Confidence Intervals, CIs, as also the smallest sample of the pairwise comparison was over 75 records (Meredith and Ridout 2014). The Hermans-Rasson test ( $r$ test) was used to estimate whether a random activity pattern was exhibited by the crested porcupine round-the-clock (Landler et al. 2019). The 95\% CIs were computed by using 10,000 bootstrap replicates (Mori et al. 2020). We tested whether moonlight had an effect on the locomotor activity patterns of the crested porcupine, by classifying moon phases as it follows: phase (1) from new moon to $1 / 4$; phase (2) from $1 / 4$ to $1 / 2$; phase (3) from $1 / 2$ to $3 / 4$ and phase (4) over $3 / 4$ and full moon. Then, we performed a chi-squared test on the numbers of records in each moon phase, to assess if they were uniform throughout the four phases (Mori et al. 2020). Similarly, we also analysed the effects of moonlight on camera-trap records of the potential predators of the crested porcupine from the same study area, i.e. the common leopard, the spotted hyaena and the honey badger.

\section{Results}

\section{Habitat selection}

We collected a total of 146 records of crested porcupine (mean per year: 17.2 \pm 15.9 , range $=1-58), 91$ in the dry season and 55 in the rainy season (Figure 1). Only rock outcrop formations were selected throughout the year and in the rainy season, whereas gallery forests, wetlands and fallows were avoided. Conversely, arboreal savannah and shrub savannah were used proportionally to their local availability throughout the year (Table 1).

\section{Patterns of activity rhythms}

The crested porcupine was mostly nocturnal with few bouts of diurnal activity (Figure $2 a)$, mostly by juveniles (at the very start or at the end of the rainy one). Throughout the 
year, activity patterns were significantly different from random according to the HermansRasson test $(r=79.42, \mathrm{P}<0.001)$. Temporal overlap of activity patterns between the rainy and the dry season was very high $\left(\Delta_{4}=0.81,95 \% \mathrm{CIs}=0.69-0.91\right.$ : Figure $\left.2 \mathrm{~b}\right)$.

Table 1. Ivlev's Electivity Indices for habitat selection of the crested porcupine in West Africa.

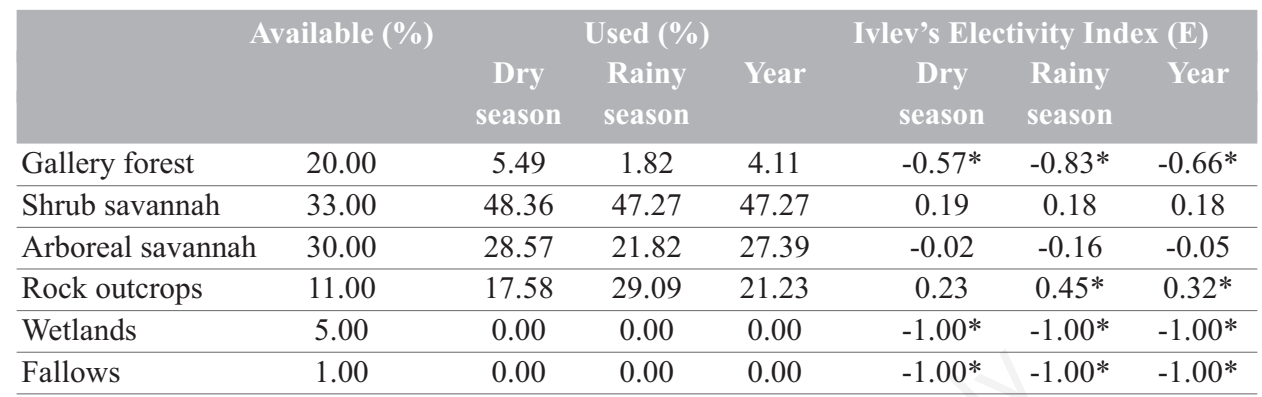

*Significant selection (positive sign) or avoidance (negative sign).

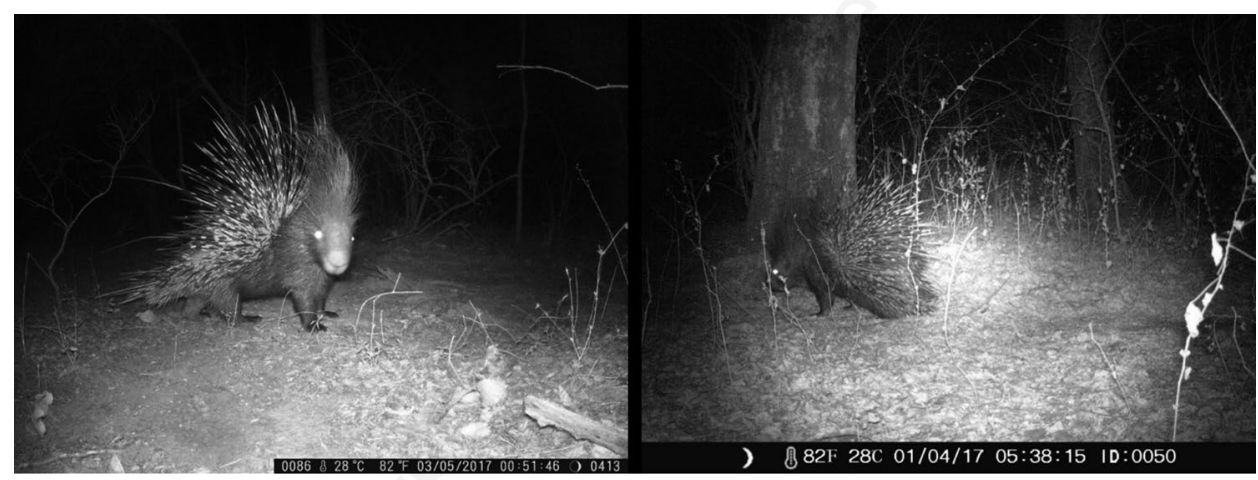

Figure 1. Individuals of crested porcupine camera-trapped in northern Benin.

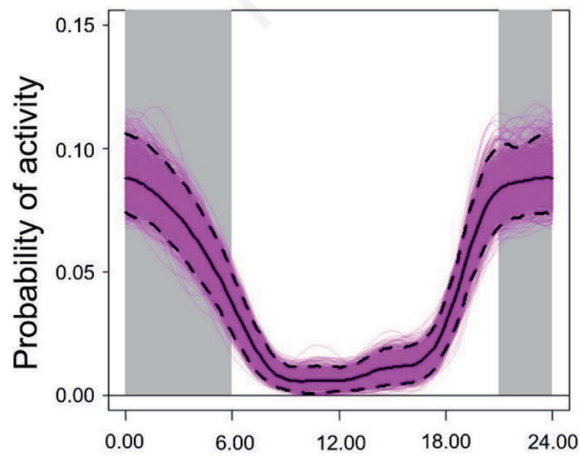

a)

Time of the day (hour)

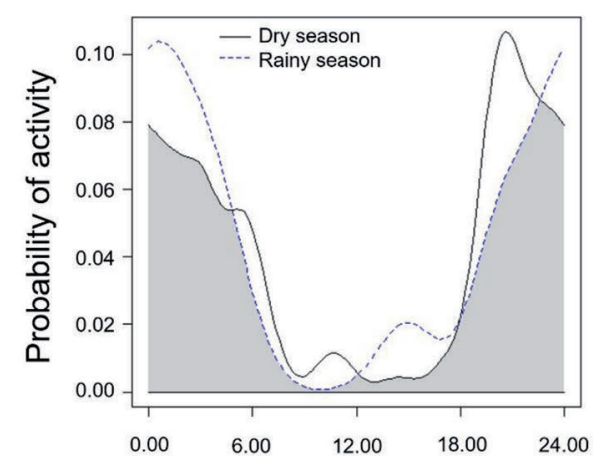

b)

Time of the day (hour)

Figure 2. Patterns of activity rhythms of the crested porcupine. a) Kernel density estimate of activity throughout the year. Purple lines represent bootstrap estimates, and dashed black lines represent $95 \%$ $\mathrm{CIs}$; b) inter-seasonal overlap of activity patterns (Kernel density estimates) of the crested porcupine in West Africa. 
Crested porcupines avoided bright moonlight nights throughout the year and were mostly active in total darkness $\left(\chi^{2}=83.85\right.$, dof $\left.=3, \mathrm{P}<0.01\right)$. Conversely patterns of activity rhythms of all potential predators were not related to moon phases (common leopard: $\mathrm{N}=50$ records, $\chi^{2}=2.16$, dof $=3, \mathrm{P}>0.25$; spotted hyaena: $\mathrm{N}=71$ records, $\chi^{2}=3.53$, dof $=3, \mathrm{P}>0.25$; honey badger: $\mathrm{N}=31$ records, $\chi^{2}=3.64$, dof $=3, \mathrm{P}>0.25$ ).

\section{Discussion}

To the best of our knowledge, this work provides the first data on the behavioural ecology of the crested porcupine in its native range (West Africa), thus providing important information on this species and bringing new interpretations on ecological data collected where it was possibly introduced, i.e. in Italy (Loy et al. 2019). The crested porcupine was shown to be a "habitat-generalist", avoiding only habitats which do not provide it with food and shelter sites, such as wetlands, gallery forests and fallows, thus fulfilling our prediction $(i)$. This behaviour mirrors habitat selection studies in central Italy, where porcupines may also use suburban areas, if covered by thick vegetation (Santini 1980; Pigozzi and Patterson 1990; Sonnino 1998; Mori et al. 2014a; Lovari et al. 2017). A similar spatial behaviour has been described in South Africa for the Cape porcupine Hystrix africaeaustralis in a savannah ecosystem and for the Indian crested porcupine $H$. indica Kerr, 1792 in the forest, where thick vegetation was reported as a pivotal determinant of habitat selection (Fattorini and Pokheral 2012; Ngcobo et al. 2019). Conversely, it selected rock outcrop formations, which are often sloping and may host den sites (Tinelli and Tinelli 1980; Filibeck et al. 1981; Monetti et al. 2005). Rock outcrop formations may provide also porcupines with natural shelter sites, preventing them to directly excavate dens (see Akram and Ilyas 2016; Talukdar et al. 2019, for $H$. indica). This may represent a further explanation for the selection of this habitat type also in West Africa. Crested porcupines were mostly active in night hours, spending daylight hours in their underground dens: therefore, also our prediction (ii) has been verified. This fits with data on this species collected in Italy (Corsini et al. 1995; Mori et al. 2014c; Mori 2017; Coppola et al. 2019). At northern latitudes, a reduction in porcupine activity has been observed during the cold months (Alkon and Saltz 1988a, b; Corsini et al. 1995). Conversely, in our tropical area, we did not detect any activity reduction in any season, which is consistent with the very constant ambient temperatures characterizing this region of Africa throughout the year. Diurnal behaviour during the afternoon was only detected at the start and at the end of the rainy seasons mostly by juvenile individuals. The peak of activity during the afternoon is a typical cub behaviour also in Italy in April-June, and it may be related to thermoregulation or synthesis of metabolites e.g. Vitamin D, necessary for growth (Coppola et al. 2019). Also, in our study area, cubs were mostly observed at the start of the rainy season, in April. This reflects the birth peak in Italy, which occurs in mid-winter with juvenile individuals starting following their parents in late March (Mori et al. 2016). The African evolutionary origin of the crested porcupine has brought this rodent to show its peak of births at the end of the African dry season, so that cub may emerge from the den at the start of the rainy season, when food is mostly available (Mori et al. 2016). Yellen (1991) and Coppola et al. (2019) reported that most of the diurnal activity of porcupines in South Africa and central Italy respectively was exerted in the surroundings of den setts. The mostly nocturnal behaviour is also confirmed by the fact that crested porcupine avoids bright moonlight nights. This dependence of porcupine activity to moon phases has also been recorded in Italy (Mori et al. 2014c; Mori 2017) and in Asia (H. indica: Alkon and Saltz 1988a; Mukherjee et al. 2018), and it 
may be related to antipredatory behaviour. Accordingly, Fattorini and Pokheral (2012) showed that Indian crested porcupines tend to range in concealed habitats and darkest nights to avoid visibility to large predators, e.g., common leopards, in Nepal. Similarly, in West Africa, crested porcupines were poorly active in moonlight nights, as we predicted (prediction iii). Preliminary information on predators occurring in our study areas suggested that all of them (the common leopard, the spotted hyaena and the honey badger) are active also at night and irrespectively of moon phases. Given the quill armor all around their bodies, porcupines represent most often an ancillary component of the diet of these predators (Henschel and Skinner 1990; Begg et al. 2003; Breuer 2005; Lovari et al. 2013; Mori et al. 2014b), and they are rarely killed. Hayward et al. (2006) reported that in Africa common leopards consume porcupines in proportion to their local availability. However, in some cases, porcupines may become important prey of large felids (Kumar 2016), and cubs can be occasionally killed by honey badgers even within their den (Arbon 2019). Furthermore, poaching pressure is generally high for the traditional medicine, for porcupine meat and because it is widely considered as a crop pest. This may bring porcupines to avoid ranging movements when and where they are visible to humans, e.g. open areas and bright nights (Laurenzi et al. 2016; Lovari et al. 2017; Talukdar et al. 2019).

\section{Conclusions}

Despite being a very common species in Italy (Loy et al. 2019), the crested porcupine is threatened with extinction in Africa, particularly in the western countries. In these areas, porcupines are widely poached for meat and for traditional medicine, as a cure for men sexual weakness, migraine, breast pain and coughing (Ouoba et al. 2020). Our work represents the first attempt to clarify the behavioural ecology of this rodent in its native range, which is necessary to address well-designed management plans. Further research is however needed to assess feeding habits and den site selection. Poaching pressure should be also locally estimated (Cerri et al. 2017) as a prerequisite for improving their conservation.

\section{Acknowledgements}

Authors would like to thank all photographers contributing observations to the project, especially OeBenin, a Benin NGO working on education and nature conservation. The Deutsche Gesellschaft für Internationale Zusammenarbeit (GIZ) provided most financial and technical support. Thanks are also due to Managers of each Protected Areas of the WAP complex, who provided permissions and technical support. Two anonymous reviewers kindly provided us with useful suggestions on our manuscript.

\section{Conflict of interest}

The authors declare no conflict of interest.

\section{Authors' contributions}

$\mathrm{AV}$ and EM conceived the study, conducted statistical analyses and wrote the first draft. $\mathrm{HO}$ and FB conducted field work. LL and GA participated in data interpretation and writing up all drafts. 


\section{References}

Akram F, Ilyas O. 2016. Den-site selection of Indian porcupine and its physical characteristics in Central India landscape. International Journal of Ecology and Environmental Sciences. 42:295-302.

Alkon PU, Saltz P. 1988a. Influence of season and moonlight on temporal-activity patterns of Indian crested porcupine (Hystrix indica). Journal of Mammalogy. 69:71-80. https://doi.org/10. 2307/1381749

Alkon PU, Saltz P. 1988b. Foraging time and the northern range limits of Indian crested porcupines (Hystrix indica Kerr). Journal of Biogeography. 15:403-408. https://doi.org/10.2307/2845271

Amori G, De Smet K. 2016. Hystrix cristata. The IUCN Red List of Threatened Species 2016: e.T10746A22232484. https://dx.doi.org/10.2305/IUCN.UK.20162.RLTS.T10746A22232484.en (a ccessed 8 November 2020).

Arbon K. 2019. Predation of porcupine Hystrix africaeaustralis in the den by honey badger Mellivora capensis. Biodiversity Observations. 10:1-3.

Begg C, Begg K, Du Toit J, Mills M. 2003. Sexual and seasonal variation in the diet and foraging behaviour of a sexually dimorphic carnivore, the honey badger (Mellivora capensis). Journal of Zoology. 260:301-316. https://doi.org/10.1017/S0952836903003789

Blight O, Josens R, Bertelsmeier C, Abril S, Boulay R, Cerdá X. 2017. Differences in behavioural traits among native and introduced colonies of an invasive ant. Biological Invasions. 19:1389-1398. https://dx.doi.org/10.1007/s10530-016-1353-5

Bonnot NC, Couriot O, Berger A, Cagnacci F, Ciuti S, De Groeve JE, Gehr B, Heurich M, Kjellander P, Kröschel M, et al. 2019. Fear of the dark? Contrasting impacts of humans versus lynx on diel activity of roe deer across Europe. Journal of Animal Ecology. 89:132-145. https://doi.org/10.1111/ 1365-2656.13161

Botts RT, Eppert AA, Wiegman TJ, Rodriguez A, Blankenship SR, Asselin EM, Garley WM, Wagner AP, Ullrich SE, Allen GR, Mooring MS. 2020. Circadian activity patterns of mammalian predators and prey in Costa Rica. Journal of Mammalogy. 101:1313-1331. https://doi.org/10.1093/ jmam$\mathrm{mal} / \mathrm{gyaa} 103$

Bowkett AE, Rovero F, Marshall AR. 2008. The use of camera-trap data to model habitat use by antelope species in the Udzungwa Mountain forests, Tanzania. African Journal of Ecology. 46:479-489. https://doi.org/10.1111/j.1365-2028.2007.00881.x

Breuer T. 2005. Diet choice of large carnivores in northern Cameroon. African Journal of Ecology. 43:97-106. https://doi.org/10.1111/j.1365-2028.2005.00551.x

Bridges AS, Noss AJ. 2011. Behavior and activity patterns. In: O'Connell AF, Nichols JD, Karanth KU, editors. Camera traps in animal ecology. Methods and Analyses. Chapter 5. New York: Springer Editions. p. 57-69.

Bruno E, Riccardi C. 1995. The diet of the crested porcupine Hystrix cristata L., 1758 in a Mediterranean rural area. Zeitschrift fur Säugetierkunde. 60:226-236.

Caravaggi A, Banks PB, Burton AC, Finlay CM, Haswell PM, Hayward MW, Rowcliffe MJ, Wood MD. 2017. A review of camera trapping for conservation behaviour research. Remote Sensing in Ecology and Conservation. 3:109-122. https://doi.org/10.1002/rse2.48

Cerri J, Mori E, Vivarelli M, Zaccaroni M. 2017. Are wildlife value orientations useful tools to explain tolerance and illegal killing of wildlife by farmers in response to crop damage? European Journal of Wildlife Research. 63:70. https://doi.org/10.1007/s10344-017-1127-0

Coppola F, Vecchio G, Felicioli A. 2019. Diurnal motor activity and "sunbathing" behaviour in crested porcupine (Hystrix cristata L., 1758). Scientific Reports. 9:1-8. https://doi.org/10.1038/s41598019-50784-y

Corsini MT, Lovari S, Sonnino S. 1995. Temporal activity patterns of crested porcupines Hystrix cristata. Journal of Zoology (London). 236:43-54. https://doi.org/10.1111/j.1469-7998.1995. tb01783.x

Cox GW. 2004. Alien species and evolution: the evolutionary ecology of exotic plants, animals, microbes, and interacting native species. Washington DC: Island Press. 377 pp.

De Luca DW, Rovero F. 2006. First records in Tanzania of the vulnerable Jackson's mongoose Bdeogale jacksoni (Herpestidae). Oryx. 40:468-471. https://doi.org/10.1017/S0030605306001396 
Di Bitetti MS, Paviolo A, De Angelo C. 2006. Density, habitat use and activity patterns of ocelots (Leopardus pardalis) in the Atlantic Forest of Misiones, Argentina. Journal of Zoology. 270:153-163. https://doi.org/10.1111/j.1469-7998.2006.00102.x

Díaz-Ruiz F, Caro J, Delibes-Mateos M, Arroyo B, Ferreras P. 2016. Drivers of red fox (Vulpes vulpes) daily activity: prey availability, human disturbance or habitat structure? Journal of Zoology. 298:128-138. https://doi.org/10.1111/jzo.12294

Dossou-Yovo ER, Brueggemann N, Jesse N, Huat J, Ago EE, Agbossou EK. 2016. Reducing soil CO2 emission and improving upland rice yield with no-tillage, straw mulch and nitrogen fertilization in northern Benin. Soil and Tillage Research. 156:44-53. https://doi.org/10.1016/j.still.2015.10.001

Drygala F, Stier N, Zoller H, Boegelsack K, Mix HM, Roth M. 2008. Habitat use of the raccoon dog (Nyctereutes procyonoides) in north-eastern Germany. Mammalian Biology. 73:371-378. https://doi.org/10.1016/j.mambio.2007.09.005

Ettiss K, Chammen M, Khorchani T. 2020. Food preferences of the crested porcupine Hystrix cristata L., 1758 (Rodentia: Hystricoidea) in South-Eastern Tunisia. Acta Zoologica Bulgarica. 72:37-42.

Fattorini N, Pokheral CP. 2012. Activity and habitat selection of the Indian crested porcupine. Ethology Ecology \& Evolution. 24:377-387. https://doi.org/10.1080/03949370.2012.705330

Filibeck U, Locasciulli O, Procacci M, Tinelli A, Tinelli P. 1981. Il trappolamento come tecnica di ricerca per studi di popolazioni dell'istrice: sperimentazione ed osservazioni nel Parco Regionale della Maremma. Atti della Società Italiana di Scienze Naturali. 122:204-216.

Gehring TM, Kohn BE, Gehring JL, Anderson EM. 2003. Limits to plasticity in gray wolf, Canis lupus, pack structure: conservation implications for recovering populations. The Canadian Field-Naturalist. 117:419-423. https://doi.org/10.22621/cfn.v117i3.744

Hamel S, Killengreen ST, Henden JA, Eide NE, Roed-Eriksen L, Ims RA, Yoccoz NG. 2013. Towards good practice guidance in using camera-traps in ecology: influence of sampling design on validity of ecological inferences. Methods in Ecology and Evolution. 4:105-113. https://doi.org/10.1111/j. 2041-210x.2012.00262.x

Hayward MW, Henschel P, O’Brien J, Hofmeyr M, Balme G, Kerley GIH. 2006. Prey preferences of the leopard (Panthera pardus). Journal of Zoology. 270:298-313. https://doi.org/10.1111/j.14697998.2006.00139.x

Henschel JR, Skinner JD. 1990. The diet of the spotted hyaenas Crocuta crocuta in Kruger National Park. African Journal of Ecology. 28:69-82. https://doi.org/10.1111/j.1365-2028.1990.tb01138.x

Hinckley A, Hawkins MT, Achmadi AS, Maldonado JE, Leonard JA. 2020. Ancient divergence driven by geographic isolation and ecological adaptation in forest dependent Sundaland tree squirrels. Frontiers in Ecology and Evolution. 8:208. https://10.3389/fevo.2020.00208

Ivlev VS. 1961. Experimental ecology of the feeding of fishes. New Haven, Connecticut: Yale University Press. 302 pp.

Karanth KU, Srivathsa A, Vasudev D, Puri M, Parameshwaran R, Kumar NS. 2017. Spatio-temporal interactions facilitate large carnivore sympatry across a resource gradient. Proceedings of the Royal Society B: Biological Sciences. 284:20161860. https://doi.org/10.1098/rspb.2016.1860

Kumar S. 2016. Porcupine, Hystrix indica is in tiger's diet, a case study, a choice of food or habit for survival in Corbett Tiger Reserve, Ramnagar, Uttrakhand, India. International Journal of Life-Sciences Scientific Research. 2:509-512.

Landler L, Ruxton GD, Malkemper EP. 2019. The Hermans-Rasson test as a powerful alternative to the Rayleigh test for circular statistics in biology. BMC Ecology. 19:1-8. https://doi.org/10.1186/ s12898-019-0246-8

Lashley MA, Cove MV, Chitwood MC, Penido G, Gardner B, DePerno CS, Moorman CE. 2018. Estimating wildlife activity curves: comparison of methods and sample size. Scientific Reports. 8:4173. https://doi.org/10.1038/s41598-018-22638-6

Laurenzi A, Bodino N, Mori E. 2016. Much ado about nothing: assessing the impact of a problematic rodent on agriculture and native trees. Mammal Research. 61:65-72. https://doi.org/10.1007/ s13364-015-0248-7

Lazzaro X. 1987. A review of planktivorous fishes: their evolution, feeding behaviours, selectivities, and impacts. Hydrobiologia. 146:97-167. https://doi.org/10.1007/BF00008764 
Lazzeri L, Senini C, Mori E. 2020. Interspecific aggressions between crested porcupines and roe deer. Animals. 10:623. https://doi.org/10.3390/ani10040623

Lovari S, Corsini MT, Guazzini B, Romeo G, Mori E. 2017. Suburban ecology of the crested porcupine in a heavily poached area: a global approach. European Journal of Wildlife Research. 63:10. https://oi.org/10.1007/s10344-016-1075-0

Lovari S, Mori E, Procaccio EL. 2020. On the behavioural biology of the mainland serow: a comparative study. Animals. 10:1669. https://doi.org/10.3390/ani10091669

Lovari S, Ventimiglia M, Minder I. 2013. Food habits of two leopard species, competition, climate change and upper treeline: a way to the decrease of an endangered species? Ethology Ecology \& Evolution. 25:305-318. https://doi.org/10.1080/03949370.2013.806362

Loy A, Aloise G, Ancillotto L, Angelici FM, Bertolino S, Capizzi D, Castiglia R, Colangelo P, Contoli L, Cozzi B, et al. 2019. Mammals of Italy: an annotated checklist. Hystrix, the Italian Journal of Mammalogy. 30:87-106. https://doi.org/10.4404/hystrix-00196-2019

Luna A, Franz D, Strubbe D, Shwartz A, Braun MP, Hernàndez-Brito D, Malihi Y, Kaplan A, Mori E, Menchetti M, et al. 2017. Reproductive timing as a constraint on invasion success in the ring-necked parakeet (Psittacula krameri). Biological Invasions. 19:2247-2259. https://doi.org/10.1007/s10530017-1436-y

Massolo A, Dani FR, Bella N. 2009. Sexual and individual cues in the peri-anal gland secretum of crested porcupines (Hystrix cristata). Mammalian Biology. 74:488-496. https://doi.org/10.1016/ j.mambio.2009.07.004

Mazzamuto MV, Valvo ML, Anile S. 2019. The value of by-catch data: How species-specific surveys can serve non-target species. European Journal of Wildlife Research. 65:68. https://doi.org/10.1007/ s10344-019-1310-6

Meredith M, Ridout M. 2014. Overview of the Overlap Package. Available from: http://cran.cs.wwu.edu/web/packages/overlap/vignettes/overlap.pdf (accessed 8 November 2020.

Monetti L, Massolo A, Sforzi A, Lovari S. 2005. Site selection and fidelity by crested porcupines for denning. Ethology, Ecology \& Evolution. 17:149-159. https://doi.org/10.1080/08927014. 2005.9522604

Monterroso P, Alves PC, Ferreras P. 2014. Plasticity in circadian activity patterns of mesocarnivores in southwestern Europe: implications for species coexistence. Behavioural Ecology and Sociobiology. 68:1403-1417. https://doi.org/10.1007/s00265-014-1748-1

Mori E. 2017. Porcupines in the landscape of fear: effects of hunting with dogs on the behaviour of a non-target species. Mammal Research. 62:251-258. https://doi.org/10.1007/s13364-0170313-5

Mori E, Ancillotto L, Lovari S, Russo D, Nerva L, Mohamed WF, Motro Y, Di Bari P, Plebani M. 2019. Skull shape and Bergmann's rule in mammals: hints from Old World porcupines. Journal of Zoology. 308:47-55. https://doi.org/10.1111/jzo.12651

Mori E., Lovari S. 2014. Sexual size monomorphism in the crested porcupine (Hystrix cristata). Mammalian Biology. 79:157-160. https://doi.org/10.1016/j.mambio.2013.07.077

Mori E, Lovari S, Sforzi A, Romeo G, Pisani C, Massolo A, Fattorini L. 2014a. Patterns of spatial overlap in a monogamous large rodent, the crested porcupine. Behavioural Processes. 107:112-118. https://doi.org/10.1016/j.beproc.2014.08.012

Mori E, Maggini I, Menchetti M. 2014b. When quills kill. The defence strategy of the crested porcupine Hystrix cristata L., 1758. Mammalia. 78:229-234. https://doi.org/10.1515/mammalia-2013-0126

Mori E, Menchetti M, Lucherini M, Sforzi A, Lovari S. 2016. Timing of reproduction and paternal cares in the crested porcupine. Mammalian Biology. 81:345-349. https://doi.org/10.1016/j. mambio.2016.03.004

Mori E, Nourisson DH, Lovari S, Romeo G, Sforzi A. 2014c. Self-defence may not be enough: moonlight avoidance in a large, spiny rodent. Journal of Zoology. 294:31-40. https://doi.org/10.1111/ jzo. 12145

Mori E, Sangiovanni G, Corlatti L. 2020. Gimme shelter: the effects of rock and moonlight on occupancy and activity pattern of an endangered rodent, the garden dormouse Eliomys quercinus. Behavioural Processes. 170:103999. https://doi.org/10.1016/j.beproc.2019.103999

Mori E, Sforzi A, Bogliani G, Milanesi P. 2018. Range expansion and redefinition of a crop-raiding ro- 
dent associated with global warming and temperature increase. Climatic Change. 150:319-331. https://doi.org/10.1007/s10584-018-2261-8

Mouzoun S, Lougbegnon TO, Codjia JTC. 2018a. Ėtude de quelques aspects ecologiques de Hystrix cristata dans les Reserves de Biosphere du Benin. Journee de la Renaissance Scientifique de l'Afrique. 2018:181-191.

Mouzoun S, Lougbegnon TO, Codjia JTC. 2018b. Population pressure and wildlife conservation in Benin biosphere reserves. Nature \& Faune. 32:71-74.

Mukherjee A, Kumara HN, Bhupathy S. 2018. Environmental determinants of activity variation of an overlooked burrowing rodent: the Indian crested porcupine. Mammalia. 82:449-459. https://doi.org/10.1515/mammalia-2017-0124

Ngcobo SP, Wilson AL, Downs C. 2019. Habitat selection of Cape porcupines in a farmland-suburban context in KwaZulu-Natal, South Africa. Mammalian Biology. 98:111-118. https://doi.org/ 10.1016/j.mambio.2019.08.004

O'Connell AF, Nichols JD, Karanth KU. 2011. Camera traps in animal ecology. Methods and analyses. New York: Springer Editions. 280 pp.

Ossi F, Ranc N, Moorcroft P, Bonanni P, Cagnacci F. 2020. Ecological and behavioral drivers of supplemental feeding use by roe deer Capreolus capreolus in a peri-urban context. Animals. 10:2088. https://doi.org/10.3390/ani10112088

Ouoba D, Dibloni OT, Mano K, Ouoba Y, Kabre BG. 2020. Role of wild mammals in traditional medicine and mystic practices in the province of Oubritenga, Burkina Faso. International Journal of Biological Chemistry Sciences. 14:1322-1340. https://doi.org/10.1111/J.1469-7998.2010.00784.X

Pigozzi G. 1986. Crested porcupines Hystrix cristata within badger setts Meles meles in the Maremma Natural Park, central Italy. Saugetierkd Mitt Band. 33:261-263.

Pigozzi G, Patterson IJ. 1990. Movements and diet of crested porcupines in the Maremma National Park, central Italy. Acta Theriologica. 35:173-180. https://doi.org/10.4098/AT.ARCH.90-21

QGIS Development Team. 2019. QGIS Geographic Information System. Open Source Geospatial Foundation Project. http://qgis.osgeo.org (accessed 7 February 2019).

Romani T, Giannone C, Mori E, Filacorda S. 2018. Use of track counts and camera trapping to estimate the abundance of roe deer in North-Eastern Italy: are they effective methods? Mammal Research. 63:477-484. https://doi.org/10.1007/s13364-018-0386-9

Rovero F, Rathbun GB, Perkin A, Jones T, Ribble DO, Leonard C, Mwakisoma RR, Doggart N. 2008. A new species of giant sengi or elephant-shrew (genus Rhynchocyon) highlights the exceptional biodiversity of the Udzungwa Mountains of Tanzania. Journal of Zoology. 274:126-133. https://doi.org/10.1111/j.1469-7998.2007.00363.x

Rovero F, Tobler M, Sanderson J. 2010. Camera trapping for inventorying terrestrial vertebrates. In: Eymann J, Degreef J, Häuser C, Monje C, editors. Manual on field recording and protocols for all taxa biodiversity inventories and monitoring. Chapter 6. Bruxelles: ABC Taxa Editions. p. $101-128$.

Santini L. 1980. The habits and influence on the environment of the Old World porcupine Hystrix cristata L. in the northernmost part of its range. Vertebrate Pest Conference Proceedings Collection. 1:149-153.

Schmidt M, Assède E, Oebel H, Fahr J, Sinsin B. 2016. Biota of the WAP complex-starting a citizenscience project for West Africa's largest complex of protected areas. Flora et Vegetatio SudanoSambesica. 19:3-6.

Soe E, Davison J, Süld K, Valdmann H, Laurimaa L, Saarma U. 2017. Europe-wide biogeographical patterns in the diet of an ecologically and epidemiologically important mesopredator, the red fox Vulpes vulpes: a quantitative review. Mammal Review. 47:198-211. https://doi.org/10.1111/ mam. 12092

Sonnino S. 1998. Spatial activity and habitat use of crested porcupine, Hystrix cristata L., 1758 (Rodentia, Hystricidae) in central Italy. Mammalia. 62:175-189. https://doi.org/10.1515/mamm. 1998.62.2.175

Talukdar NR, Choudhury P, Singh B. 2019. Current records of porcupine in northeastern India: distribution, habitat preference and conservation. Tropical Ecology. 60:41-51. https://doi.org/10.1007/s42965-019-00005-4 
Tinelli A, Tinelli P. 1980. Le tane di istrice e di tasso. Censimento e densità delle tane nella Riserva Presidenziale di Castelporziano per la conservazione dell'istrice e del tasso. Segretariato Generale della Presidenza della Repubblica. Tenuta di Castelporziano, Rome. 24 pp.

Tobler MW, Carrillo-Percastegui SE, Leite Pitman R, Mares R, Powell G. 2008. An evaluation of camera traps for inventorying large- and medium-sized terrestrial rainforest mammals. Animal Conservation. 11:169-178.https://doi.org/10.1111/j.1469-1795.2008.00169.x

Trucchi E, Facon B, Gratton P, Mori E, Stenseth NC, Jentoft S. 2016. Long live the alien: is high genetic diversity a pivotal aspect of crested porcupine (Hystrix cristata) long-lasting and successful invasion? Molecular Ecology. 25:3527-3539. https://doi.org/10.1111/mec.13698

Trucchi E, Sbordoni V. 2009. Unveiling an ancient biological invasion: molecular analysis of an old European alien, the crested porcupine (Hystrix cristata). BMC Evolutionary Biology. 9:109. https://doi.org/10.1186/1471-2148-9-109

Valeix M, Loveridge AJ, Chamaillé-Jammes S, Davidson Z, Murindagomo F, Fritz H, Macdonald DW. 2009. Behavioral adjustments of African herbivores to predation risk by lions: spatiotemporal variations influence habitat use. Ecology. 90:23-30. https://doi.org/10.1890/08-0606.1

Warnes GR, Bolker B, Bonebakker L, Gentleman R, Liaw WHA, Lumley T, Maechler M, Magnusson A, Moeller S, Schwartz M, Venables B. 2014. Gplots: various R programming tools for plotting data. Available online at: http://CRAN.R-project.org/package=gplots

Yellen JE. 1991 Small Mammals: !Kung San Utilization and the Production of Faunal Assemblages. Journal of Anthropological Archaeology. 10:1-26. https://doi.org/10.1016/0278-4165(91) 90019-T

This article is distributed under the terms of the Creative Commons Attribution 